The University of Maine

\title{
DigitalCommons@UMaine
}

Earth Science Faculty Scholarship

Earth Sciences

$1-20-1994$

\section{Two-hundred-year Record of Biogenic Sulfur in a South Greenland Ice Core (20D)}

\author{
P. Y. Whung \\ E. S. Saltzman \\ M.J. Spencer \\ Paul Andrew Mayewski \\ University of Maine, paul.mayewski@maine.edu \\ N. Gundestrup
}

Follow this and additional works at: https://digitalcommons.library.umaine.edu/ers_facpub

Part of the Atmospheric Sciences Commons, Climate Commons, Geochemistry Commons, Glaciology Commons, and the Hydrology Commons

\section{Repository Citation}

Whung, P. Y.; Saltzman, E. S.; Spencer, M. J.; Mayewski, Paul Andrew; and Gundestrup, N., "Two-hundred-year Record of Biogenic Sulfur in a South Greenland Ice Core (20D)" (1994). Earth Science Faculty Scholarship. 238.

https://digitalcommons.library.umaine.edu/ers_facpub/238 


\title{
Two-hundred-year record of biogenic sulfur in a south Greenland ice core (20D)
}

\author{
P.-Y. Whung and E. S. Saltzman \\ Rosentiel School of Marine and Atmospheric Sciences, University of Miami, Florida \\ M. J. Spencer and P. A. Mayewski \\ Institute for the Study of Earth, Oceans, and Space, University of New Hampshire, Durham \\ N. Gundestrup \\ Department of Geophysics, The Niels Bohr Institute, University of Copenhagen, Denmark
}

The concentration of methanesulfonic acid (MSA) was determined in a shallow south central Greenland ice core (20D). This study provides a high-resolution record of the DMS-derived biogenic sulfur in Greenland precipitation over the past 200 years. The mean concentration of MSA is $3.30 \mathrm{ppb}(\sigma=2.38 \mathrm{ppb}, \mathrm{n}=1134)$. The general trend of MSA is an increase from 3.01 to $4.10 \mathrm{ppb}$ between 1767 and 1900 , followed by a steady decrease to $2.34 \mathrm{ppb}$ at the present time. This trend is in marked contrast to that of non-sea-salt sulfate (nss $\mathrm{SO}_{4}{ }^{2-}$ ), which increases dramatically after 1900 due to the input of anthropogenic sulfur. The MSA fraction $\left(\left(\mathrm{MSA} /\left(\mathrm{MSA}+\mathrm{nss} \mathrm{SO}_{4}{ }^{2-}\right)\right) * 100\right)$ ranges from a mean of $15 \%$ in preindustrial ice to less than $5 \%$ in recent ice. These MSA fractions suggest that approximately 15 to $40 \%$ of the sulfur in recent Greenland ice is of biological origin. It is suggested that there is a significant lowlatitude component to the biogenic sulfur in the core and that variations in the MSA fraction reflect changes in the relative strengths of low- and high-latitude inputs. The data show no evidence for a strong dependence of dimethyl sulfide (DMS) emissions on sea surface temperature during the last century. There is also no indication that the yield of MSA from DMS oxidation has been altered by increased $\mathrm{NO}_{\mathrm{x}}$ levels over the North Atlantic during this period.

\section{INTRODUCTION}

Previous studies of Greenland ice have shown a threefold increase in non-sea-salt sulfate concentrations over preindustrial levels since 1900 . This increase presumably reflects the increasing atmospheric sulfur burden due to industrialization in the northern hemisphere and its incorporation into polar snow [Herron and Langway, 1985; Neftel et al., 1985; Mayewski et al., 1986]. In recent years it has been demonstrated that the oceanic source of reduced sulfur gases (principally dimethyl sulfide) constitutes the predominant flux of biogenic sulfur on a global basis [Andreae, 1990; Bates et al., 1992] and should be taken into account in regional assessments of atmospheric sulfur sources [Berresheim,

Copyright 1994 by the American Geophysical Union.

Paper number 93JD02732.

0148-0227/94/93JD-02732\$05.00
1987; Leck, 1989; Turner et al., 1989; Andreae, 1990; Berresheim et al., 1990]. Greenland is located in a region of intense seasonal biological productivity, involving phytoplankton blooms of major dimethyl sulfide (DMS) producing species. Hence variations in the biogenic component of the atmospheric sulfur over Greenland could provide a major source of variability for the sulfate levels in Greenland snow and ice. This study is an attempt to investigate the distribution of methanesulfonate (MSA) in a shallow ice core from south central Greenland in order to evaluate the importance of biogenic sulfur to the atmospheric sulfur budget of the Arctic and its variability over the last 200 years.

Methanesulfonate is a product of the atmospheric oxidation of DMS. The concentration of MSA over the oceans has been demonstrated to have significant regional and seasonal variations relating, in general, to the patterns of oceanic productivity and sea surface DMS concentrations [Saltzman et al., 1983, 1986; Ayers et al., 1986, 1991; Burgermeister and Georgii, 1989]. Ayers et 
al. [1986] reported the presence and seasonality of MSA in a shallow Antarctic ice core. A recent study of the Vostok ice core [Legrand et al., 1991] has demonstrated a significant inverse correlation between ice core MSA and isotopic temperature over a complete glacial/interglacial cycle, confirming a trend observed previously in the Dome $C$ core [Saigne and Legrand, 1987]. This study represents the first high-resolution record of MSA in the Greenland ice sheet.

\section{METHODS}

The 20D site is located at an elevation of $2615 \mathrm{~m}$ in south central Greenland $\left(65.01^{\circ} \mathrm{N}, 44.87^{\circ} \mathrm{W}\right)$. The 20D site is $40 \mathrm{~km}$ southwest from the Dye 3 site and the accumulation rates range from 6.7 to $81 \mathrm{~g} / \mathrm{cm}^{2} / \mathrm{yr}\left(\mathrm{H}_{2} \mathrm{O}\right.$ eq.) with a mean value of $41 \mathrm{~g} / \mathrm{cm}^{2} / \mathrm{yr}$. The 20D ice core was recovered in 1984 using a 4" PICO electromechanical drill [Mayewski et al., 1986]. The 20D ice core hags a total length of $116 \mathrm{~m}$ and covers the period from 1767 to 1984. The firn/ice transition of the 20D core is at approximately $52 \mathrm{~m}$. Seasonal melting can occur at this site, and sporadic melt layers are present in the core. However, the average thickness of melt layers is less than $2 \mathrm{~cm}$ and they represent only a small fraction of the total length of the core. A total of 1134 sections were cut, representing approximately eight samples per year. Major anions and cations were analyzed by the Glacier Research Group at the University of New Hampshire [Mayewski et al., 1986, 1990] and oxygen isotopes (del-18 $\mathrm{O}$ ) were measured at the University of Copenhagen on the same samples. The 20D ice core was dated using $d \mathrm{del}^{-18} \mathrm{O}$ and total $\beta$-activity measurements from this core and another core located $4 \mathbf{k m}$ to the northeast. The accuracy of the dating is \pm 1 year and the records of volcanic events were assumed to occur on or very close to the years of eruption [Mayewski et al., 1986].

Aliquots of these samples for MSA measurements were pipetted from remelted ice samples and were analyzed at the University of Miami. MSA concentrations were determined by chemically suppressed ion chromatography with AG4/AS4 columns and an AMMS membrane suppressor (Dionex Corporation, Sunnyvale, California). Samples were loaded by syringe onto a precolumn (Ion Pac), rather than a fixed sample loop, in order to allow variable volume injections and minimize the water depression during the run. A sample volume of $3 \mathrm{ml}$ was used for most samples. The eluent and regenerant used were $3.75 \mathrm{mM} \mathrm{NaOH}$ (Mallinckrodt, 50\% (W/W), 2 $\mathrm{mV} / \mathrm{min}$ ), and $11.25 \mathrm{mM} \mathrm{H}_{2} \mathrm{SO}_{4}$, respectively. Before preparing the $\mathrm{NaOH}$ eluent, Milli-Q $\mathrm{H}_{2} \mathrm{O}$ was degassed using 99.995 purified $\mathrm{He}$ to minimize the formation of $\mathrm{Na}_{2} \mathrm{CO}_{3}$ due to the uptake of $\mathrm{CO}_{2}$. An AG8 or Aminopak column was used before the injection valve in order to retain carbonate and other ionic impurities in the eluent during the run. Strongly retained anions in the samples, such as nitrate, sulfate, and carbonate, were eluted from the column using a strong (100 mM) $\mathrm{NaOH}$ eluent between samples. Under our chromatographic conditions the retention time for MSA is approximately $15 \mathrm{~min}$ and it is well resolved from organic acids such as pyruvate. The precision of the analysis is better than $\pm 5 \%(1 \sigma)$ at 1 ppb. The detection limit of the method is a function of sample volume. For a 3-ml sample, the detection limit is approximately $0.15 \mathrm{ppb}$. A number of the ice core samples were analyzed by standard additions, in order to insure that there were no losses from self-elution through the precolumn. This is of particular concern for weakly retained anions such as MSA and with samples which may vary widely in ionic content, for example, in ice core samples with volcanic sulfate peaks. These tests indicated quantitative trapping of MSA by the precolumn in all cases.

Non-sea-salt sulfate (nss $\mathrm{SO}_{4}{ }^{2-}$ ) is calculated from the measured concentrations of $\mathrm{SO}_{4}{ }^{2-}$ and $\mathrm{Na}^{+}$, assuming that the sea-salt component has the $\mathrm{Na}^{+} / \mathrm{SO}_{4}{ }^{2-}$ weight ratio of seawater (0.2517). The uncertainty in each measurement is approximately $\pm 5 \%(1 \sigma)$. In this core the sea-salt component of the total sulfate has a mean of $8.7 \pm 12.5 \%$ $(n=1107)$. The total uncertainty in the nss $\mathrm{SO}_{4}{ }^{2-}$ is therefore of the order of $\pm 7 \%(1 \sigma)$.

Previous studies of marine aerosols and precipitation have utilized the $\mathrm{MSA} / \mathrm{nss} \mathrm{SO}_{4}{ }_{4}^{2-}$ ratio in order to examine the relationship between these species and the origin of sulfur in marine air masses. A better measure of this relationship is the "MSA fraction," which we define as the ratio of MSA to the sum of MSA and nss $\mathrm{SO}_{4}{ }^{2-}$. The $\mathrm{MSA} / \mathrm{nss} \mathrm{SO}_{4}{ }^{2-}$ ratio and the MSA fraction are essentially equivalent at the low ratios typical of low-latitude marine air (2-10\%). However, in the polar regions, MSA can make up a substantial fraction of the total sulfur (VI). In these cases the MSA/nss $\mathrm{SO}_{4}{ }^{2-}$ ratio becomes a highly nonlinear function of the MSA fraction. For this reason we use the MSA fraction throughout this paper and recommend its use in future studies. The use of this term does not imply that MSA and nss $\mathrm{SO}_{4}{ }^{2-}$ are necessarily the only products formed from the oxidation of DMS in the atmosphere.

\section{RESULTS AND DISCUSSION}

Depth profiles of MSA and non-sea-salt sulfate concentrations and the MSA fraction are shown in Figure 1. Smoothed depth profiles (shown as solid curves) are superimposed on the raw data. These were constructed using a 20-point (approximately 3 years) running average of the raw data.

The mean concentration of MSA in the 20D ice core is $3.30 \pm 2.38 \mathrm{ppb}(1 \sigma, \mathrm{n}=1134)$. The mean MSA concentration gradually increases from $3.01 \pm 1.58 \mathrm{ppb}(1 \sigma$ $, n=45)$ to $4.10 \pm 1.99 \mathrm{ppb}(1 \sigma, \mathrm{n}=82)$ between 1767 and 1899 and decreases to almost a factor of 2 to a present-day value of $2.34 \pm 1.63 \mathrm{ppb}(1 \sigma, \mathrm{n}=113)$ between 1964 and 1984. The MSA concentration ranges from 0.16 to 38.12 $\mathrm{ppb}$ in the 20D ice core. In contrast to the MSA record, 


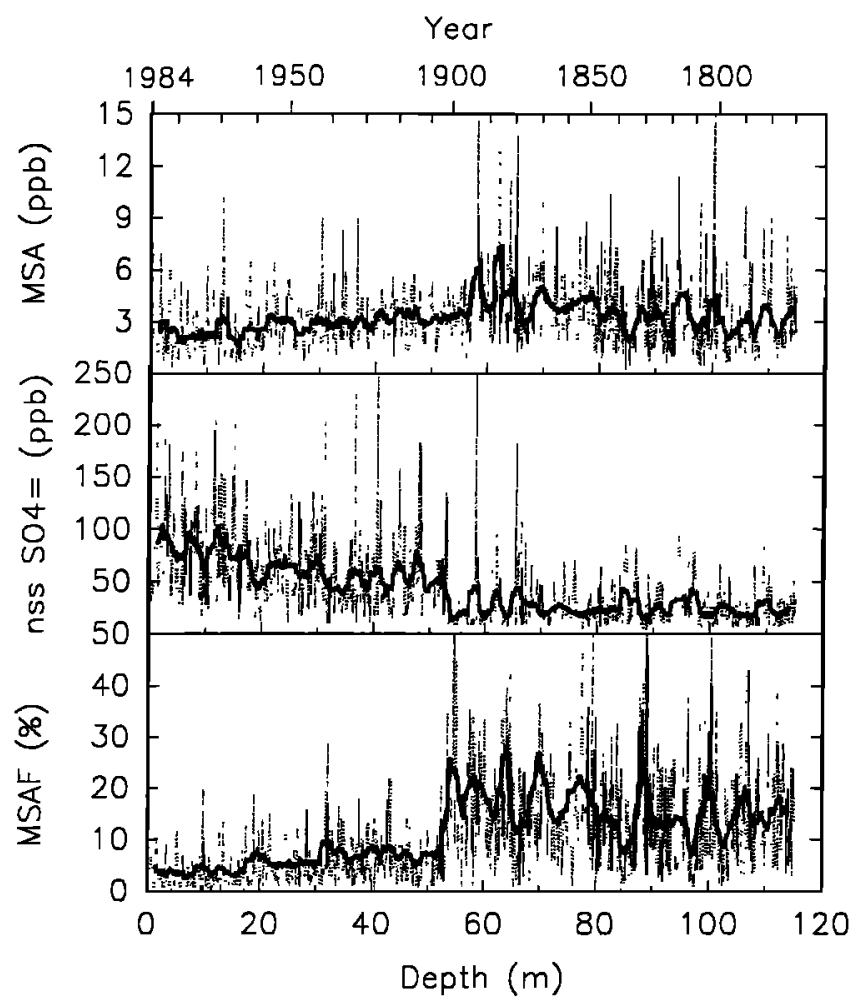

Fig. 1. Depth profiles of methanesulfonic acid (MSA), nss $\mathrm{SO}_{4}{ }^{2-}$, and MSA fractions in the 20D ice core. The dotted lines are the raw data of MSA, nss $\mathrm{SO}_{4}{ }^{2-}$, and MSA fractions. The solid curves were constructed using a 20-point (approximately 3 years) running average of the raw data.

the mean concentration of nss $\mathrm{SO}_{4}{ }^{2-}$ has increased by a factor of 3 since approximately 1900 (Figure 1). A sharp increase in nss $\mathrm{SO}_{4}{ }^{2-}$ occurred between 1900 and 1910, which has been attributed to an increase in volcanic emissions [Mayewski et al., 1986]. Because MSA is derived from biogenic dimethyl sulfide, the decreasing MSA concentrations after 1900 argue strongly against the idea that the increase in nss $\mathrm{SO}_{4}{ }^{2-}$ levels since the beginning of the industrial period is due to biogenic sulfur sources.

In terms of short-term variability there are pronounced MSA and nss $\mathrm{SO}_{4}{ }^{2-}$ cycles with a period of roughly 10 years. These cycles do not appear in other ionic constituents such as $\mathrm{Cl}^{-}$and $\mathrm{NO}_{3}^{-}$and del-18 $\mathrm{O}$. The amplitude of the MSA cycles varies with depth in the core, with the largest amplitudes in the deepest sections of the core. There appears to be a distinct decrease in the amplitude of these decadal MSA fluctuations at or near the beginning of the twentieth century. The amplitude of the 10-year cycles of nss $\mathrm{SO}_{4}{ }^{2-}$ remains more or less constant throughout the whole core. The origin of these cycles is not known, but their frequency suggests that they may be related to climatic variations in the surface oceans. We have compared these records with the Arctic sea-ice extent and the North Atlantic Oscillation (NAO) records. The variability of the Arctic sea-ice extent over the period of 1953 and 1984 showed a 4- to 6-year cycle in the western Arctic and a decadal cycle in the eastern Arctic [Walsh and Johnson, 1979; Mysak and Manak, 1989]. The NAO phenomena have a frequency of about 7 to 8 years during the period of 1960-1980 [Rogers, 1984]. Although the approximately 10-year cycles of MSA and nss $\mathrm{SO}_{4}{ }^{2-}$ are similar in frequency to those changes in seaice extent and the NAO phenomena, there is no obvious correlation between the amplitude of the MSA signal and the intensity of these events during the last century.

The mean MSA fraction over the whole core is $11.9 \pm$ $10.5(1 \sigma, n=1107)$. Prior to 1900 the MSA fraction ranged from 0.3 to $71.5 \%$ with a mean of $15.8 \pm 11.1 \%$ (1 $\sigma$ ,$n=628$ ). These variations occur with roughly a 10 -year periodicity, primarily reflecting the short-term variability in MSA mentioned above. A step function decrease in MSA fraction occurred between 1900 and 1910. The mean value of MSA fraction dropped from $17.8 \pm 14.7 \%$ ( 1 $\sigma, n=34)$ between 1900 and 1905 to $6.9 \pm 4.8 \%(1 \sigma, n=21)$ between 1906 and 1910. After 1910 the ratio decreased steadily from $6.35 \pm 3.87 \%(1 \sigma, n=53,1910-1920)$ to a present value of $3.75 \pm 4.01 \%(1 \sigma, n=69,1975-1984)$. The amplitude of short-term variations decreased to approximately $\pm 2 \%$ between 1910 and 1984 .

On a timescale of years the variations of MSA do not follow those of nss $\mathrm{SO}_{4}{ }^{2-}$ over the length of the whole core. The depth profiles of annual mean MSA and nss $\mathrm{SO}_{4}{ }^{2-}$ concentrations in the $20 \mathrm{D}$ ice core are shown in Figure 2. One would expect to find a strong correlation between the variations of MSA and those of nss $\mathrm{SO}_{4}{ }^{2-}$ during the preindustrial period because the primary source origin of these two compounds is biogenic sulfur. The preindustrial record exhibits a very complex relationship between MSA and nss sulfate. Although there are brief periods of strong positive correlation, the preindustrial record as a whole does not exhibit a statistically significant correlation as shown by a cross-correlation analysis. The most striking example of correlation occurs during the two large MSA peaks between 1880 and 1890 , which correspond to the last two of three large sulfate peaks. The first sulfate peak of this group (1875) has been identified as the Hekla volcanic eruption. The MSA record suggests that the latter two peaks are of biogenic rather than volcanic origin. The overall lack of correlation between MSA and non-sea-salt sulfate in the preindustrial record can be interpreted in one of the following ways: (1) depositional and/or postdepositional factors influence the distributions of these compounds in the ice core, (2) the biogenic source of sulfur is not the dominant source of non-sea-salt sulfate in preindustrial ice, or (3) the biogenic source is characterized by widely varying MSA fractions.

The concentrations of ionic constituents in precipitation can be strongly influenced by the precipitation rate. To evaluate the importance of changes in precipitation rate on MSA trends, we have calculated the depositional flux of MSA (in units of $\mathrm{gS} / \mathrm{cm}^{2} / \mathrm{yr}$ ) from the product of the MSA concentration and the annual snow accumulation 

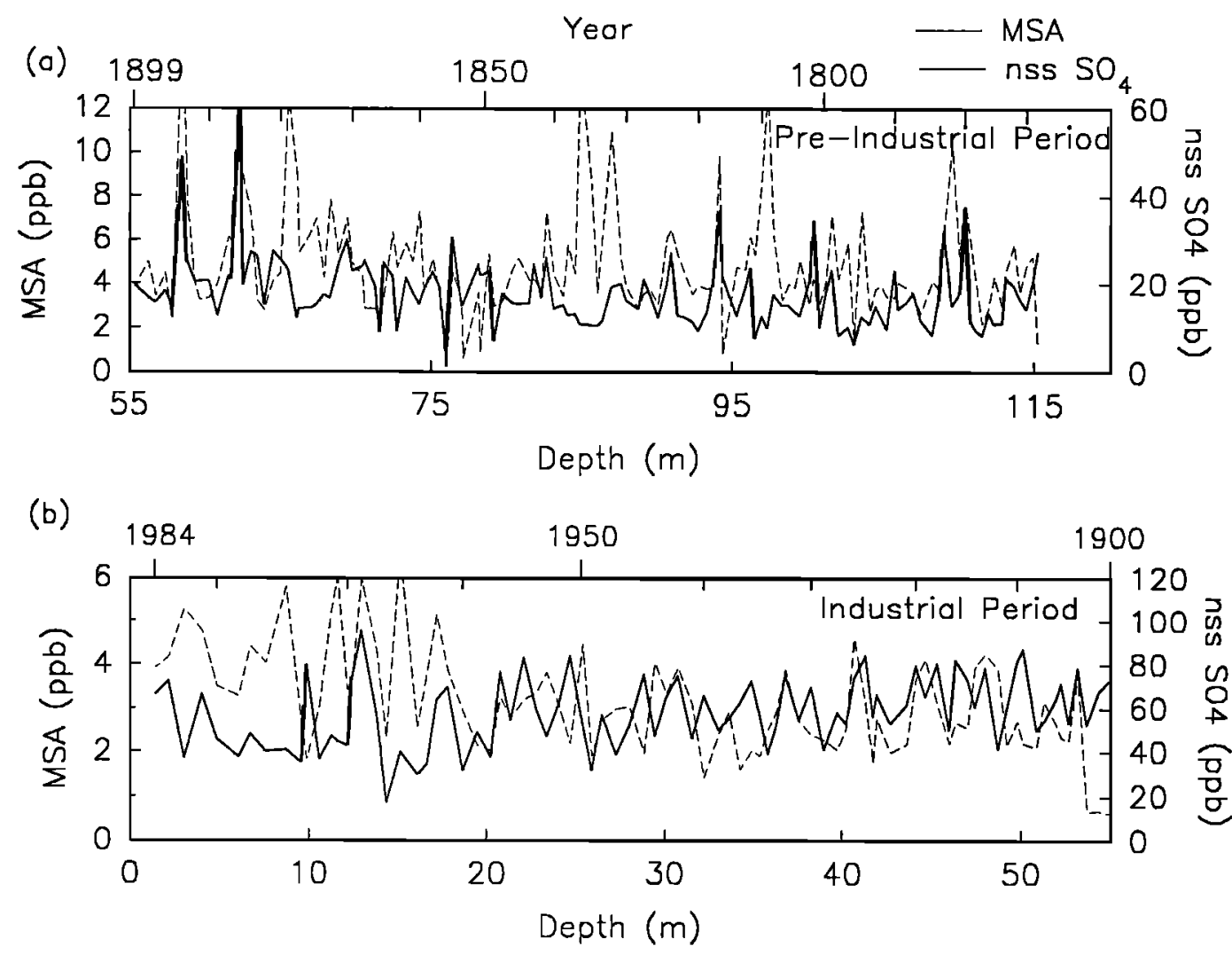

Fig. 2. Depth profiles of annual mean concentrations of $\mathrm{MSA}$ and $\mathrm{nss} \mathrm{SO}_{4}{ }^{2-}$ in the $20 \mathrm{D}$ ice core during (1) the preindustrial period (prior to 1900) and (2) the industrial period (after 1900).

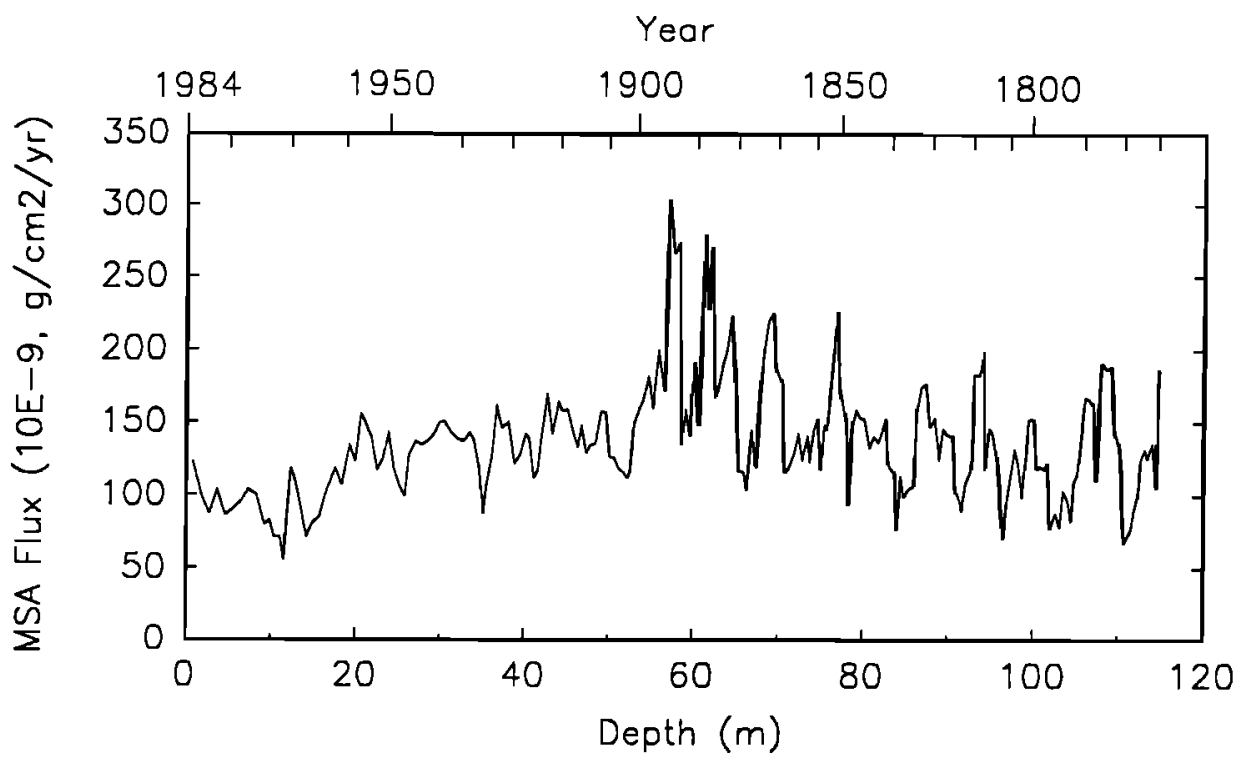

Fig. 3. The depositional flux of MSA in the $20 \mathrm{D}$ ice core. The data plotted are constructed using 20-point running average of the raw MSA depositional flux data.

rate (Figure 3). The snow accumulation rate as a function of time was obtained directly from the chronology of the core, which is in turn based on annual cycles of del- ${ }^{18} \mathrm{O}$. The depth profile of this flux is shown as a 20-point running average. Although the variations in MSA flux are dampened relative to those of MSA concentration, the overall trend is present. This result confirms that real changes in the deposition rate of MSA have occurred.
The depositional flux of MSA and non-sea-salt sulfate in ice consists of two components: wet and dry deposition. One method which has been used to attempt to resolve these components is the relationship between the flux for an aerosol-borne species and the snow accumulation rate, based on the simple assumption that

$$
\mathrm{F}_{\mathrm{MSA}}=\mathrm{C}_{\mathrm{MSA}, \mathrm{air}} * \mathrm{~V}_{\mathrm{d}}+\mathrm{C}_{\mathrm{MSA}, \text { air }}{ }^{*} \mathrm{~S}_{\mathrm{MSA}} * \mathrm{~A}_{\mathrm{H} 2 \mathrm{O}}
$$


where $\mathrm{F}_{\mathrm{MSA}}$ and $\mathrm{A}_{\mathrm{H} 2 \mathrm{O}}$ are depositional flux of MSA and accumulation rate of water $\left(\mathrm{g} / \mathrm{cm}^{2} / \mathrm{yr}\right), \mathrm{C}_{\mathrm{MSA}}$, air is the atmospheric concentration of MSA, $V_{d}$ is the deposition velocity of MSA, and $S$ is the dimensionless scavenging ratio for MSA ( $\mathrm{S}_{\mathrm{MSA}}=\mathrm{C}_{\mathrm{MSA} \text {,precip }} / \mathrm{C}_{\mathrm{MSA} \text {,air }}, \mathrm{C}_{\mathrm{MSA} \text {,precip }}$ is the MSA concentration in precipitation). Assuming that atmospheric concentrations of aerosol-borne ionic species are not related to the snow accumulation rate and that both the dry deposition velocity and the scavenging ratios are invariant with snow accumulation rate, we would expect to observe a straight line on a plot of total MSA flux versus snow accumulation rate, with a slope of $S$ and a $y$ intercept equivalent to the dry deposition rate. Also inherent in this treatment is the assumption that postdepositional processes do not significantly modify the observed signals. For both MSA and non-sea-salt sulfate in the 20D ice core the $y$ intercept is not significantly different from zero at $99 \%$ confidence (Figure $4 a, 4 b$ ). This suggests that variations in depositional processes may not play a dominant role in determining the MSA/nss $\mathrm{SO}_{4}{ }^{2-}$ ratios in this ice core. This conclusion is supported by recent size distribution measurements of aerosol MSA and sulfate in central Greenland (Whung and Saltzman, unpublished data, 1993). Those measurements suggest that most $(70 \%)$ of the MSA, like sulfate, resides on particles less than $2.4 \mu \mathrm{m}$ diameter. Further work is needed to characterize the depositional characteristics of these aerosols under field conditions.

The relationship between MSA and sodium was examined to further assess the possibility that the depositional characteristics of MSA might be significantly different from those of non-sea-salt sulfate. Sodium concentrations remained relatively constant at 20D over the last 200 years (Figure 5), with a mean concentration of $10.5 \pm 16.1 \mathrm{ppb}(1 \sigma, \mathrm{n}=1142)$. Several sodium peaks of approximately 10 years in duration occur; however, none of these correspond to peaks in MSA. Sodium and MSA are not significantly correlated in the core $(R=0.032, n=$ 1134). These results suggest that the deposition of MSA is not related to the abundance of sea-salt and that stormrelated transport patterns which are important for sodium [Davidson et al., 1985] are probably not a major source of MSA.

Radiative transfer calculations suggest that tropospheric sulfate aerosols are a significant component of the planetary albedo [Shaw, 1983; Charlson et al., 1987, 1992]. Solar radiation can be affected directly and indirectly by sulfate aerosols. This raises the possibility
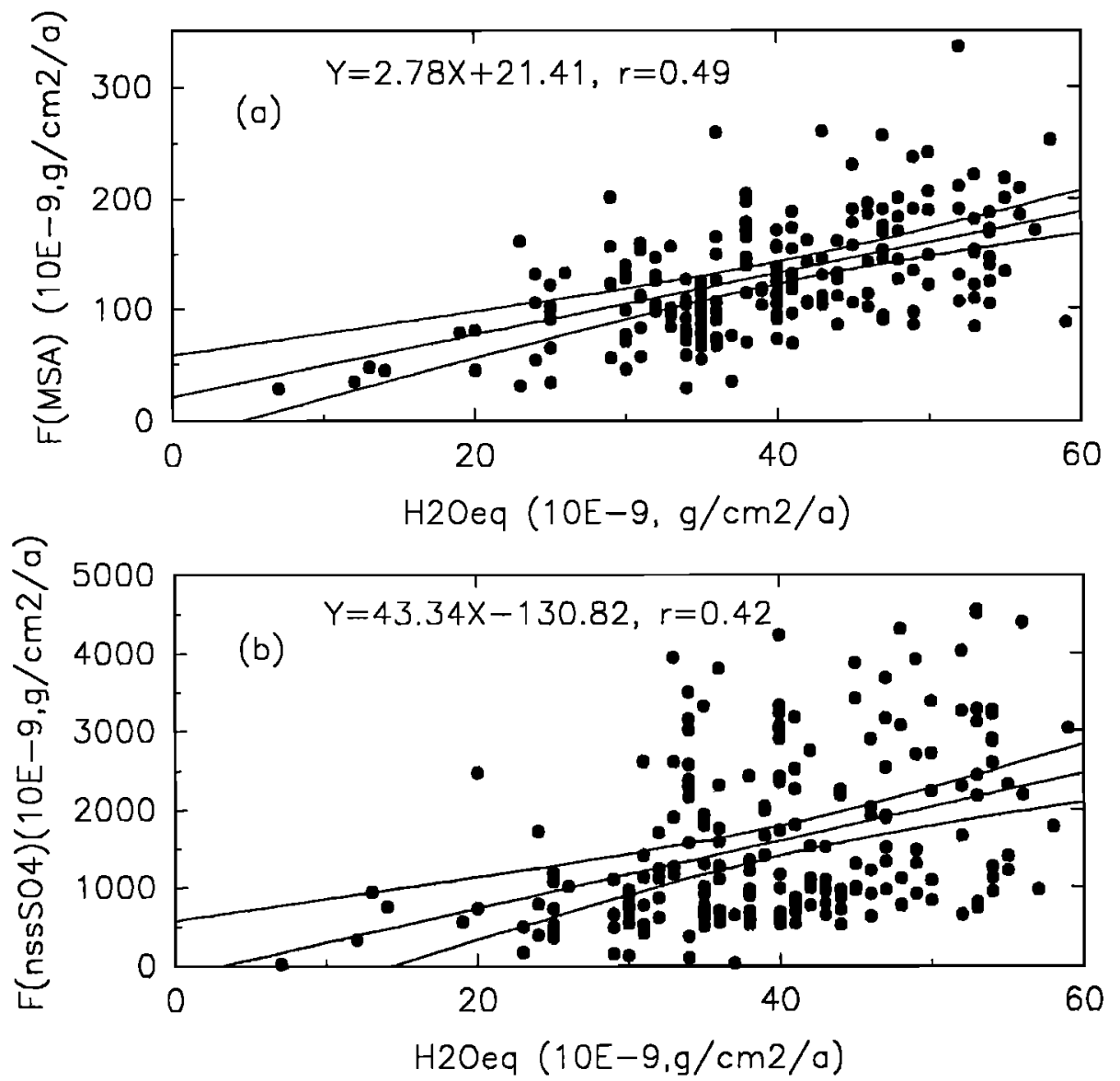

Fig. 4. The relationship between annual depositional flux of MSA and nss $\mathrm{SO}_{4}{ }^{2-}$ and snow accumulation rate ( $\left.\mathrm{H}_{2} \mathrm{Oeq}\right)$. (a) Annual mean flux of MSA (g/cm $\left./ \mathrm{yr}\right)$ versus $\mathrm{H}_{2} \mathrm{O}$ accumulation rate $\left(\mathrm{g} / \mathrm{cm}^{2} / \mathrm{yr}\right)$. (b) Annual mean flux of nss $\mathrm{SO}_{4}{ }^{2-}\left(\mathrm{g} / \mathrm{cm}^{2} / \mathrm{yr}\right)$ versus $\mathrm{H}_{2} \mathrm{O}$ in the $20 \mathrm{D}$ ice core. The solid curves represent the first-order regressions with $99 \%$ confidence intervals. 
that the biogenic sulfur cycle may provide a feedback loop for climate control; i.e., changes in temperature may affect the sea-to-air flux of DMS and vice versa [Show, 1983; Charlson et al., 1987]. A comparison of the MSA record with that of del- ${ }^{18} \mathrm{O}$ (Figure 5) shows that there is no obvious correlation between local climate at the core site and MSA. However, the intercomparison of a 5-year running average of MSA anomalies (the difference

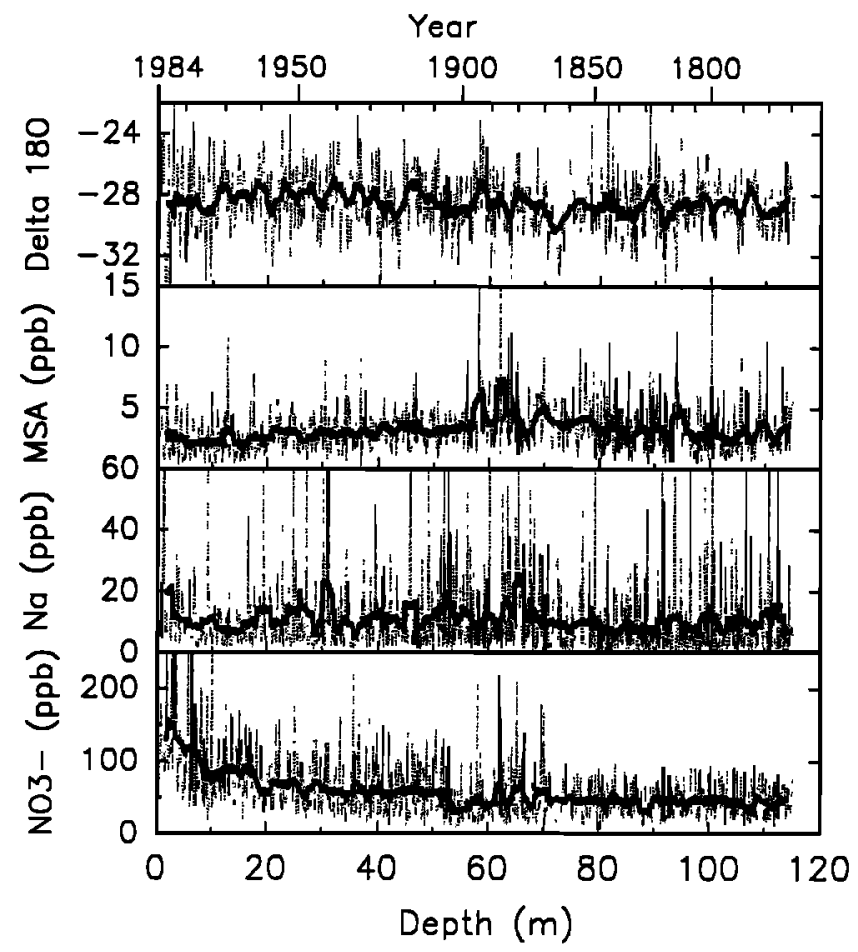

Fig. 5. Depth profiles of $\mathrm{NO}_{3}^{-}, \mathrm{Na}^{+}, \mathrm{MSA}$, and ${ }^{-1 e l-}{ }^{18} \mathrm{O}$ in the 20D ice core. The dotted lines are raw data for $\mathrm{NO}_{3}^{-}, \mathrm{Na}^{+}$, $\mathrm{MSA}$, and del- ${ }^{18} \mathrm{O}$. The solid lines are data which were constructed using 20-point running averages of the raw data. between the MSA concentration and the mean MSA concentration) [Whung, 1991] with that of the North Atlantic sea surface temperature for the period between 1850 and 1984 [Jones et al., 1986; Wu et al., 1990] (Figure 6) shows a negative correlation.

The steady decrease in MSA after 1900 raises the question of whether the onset of pollution over the North Atlantic may have altered the branching ratio of MSA and non-sea-salt sulfate during the oxidation of DMS. There are two polential mechanisms by which this could occur. First, increasing $\mathrm{NO}_{\mathrm{x}}$ levels could interact with gas phase intermediate sulfur radicals produced during oxidation of DMS by $\mathrm{OH}$. It has been demonstrated in laboratory work that the presence of $\mathrm{NO}_{x}$ can alter the product distribution of DMS oxidation by the formation of $\mathrm{CH}_{3} \mathrm{SNO}$ and possibly other adducts [Hatakeyama and Akimoto, 1983; Niki et al., 1983; Grosjean, 1984; Wallington et al., 1986; Barnes et al., 1988; Daykin and Wine, 1990]. However, the rates of adduct formation are sufficiently slow that at ambient levels of $\mathrm{NO}_{\mathrm{x}}$, even today, oxygen addition should dominate. The second mechanism is oxidation of DMS by the nitrate radical $\left(\mathrm{NO}_{3}\right)$ which is formed from the reaction of $\mathrm{NO}_{2}$ with ozone [Tyndall and Ravishankara, 1989]. The levels of $\mathrm{NO}_{2}$ and $\mathrm{O}_{3}$ have probably increased over the North Atlantic during this century. Although the product distribution of the reaction of DMS with the nitrate radical is not fully known, the production of $\mathrm{HNO}_{3}$ has been observed in laboratory studies, suggesting that $\mathrm{H}$ abstraction is the major pathway [Jensen et al., 1991]. The abstraction pathway is thought to be responsible for the production of sulfur dioxide or sulfate, rather than MSA. In polar regions the role of nitrate radical as an oxidant of DMS is probably minimal, because the nitrate radical is photolyzed rapidly during the polar summer when DMS emissions are at a maximum. However, nighttime oxidation of DMS via the

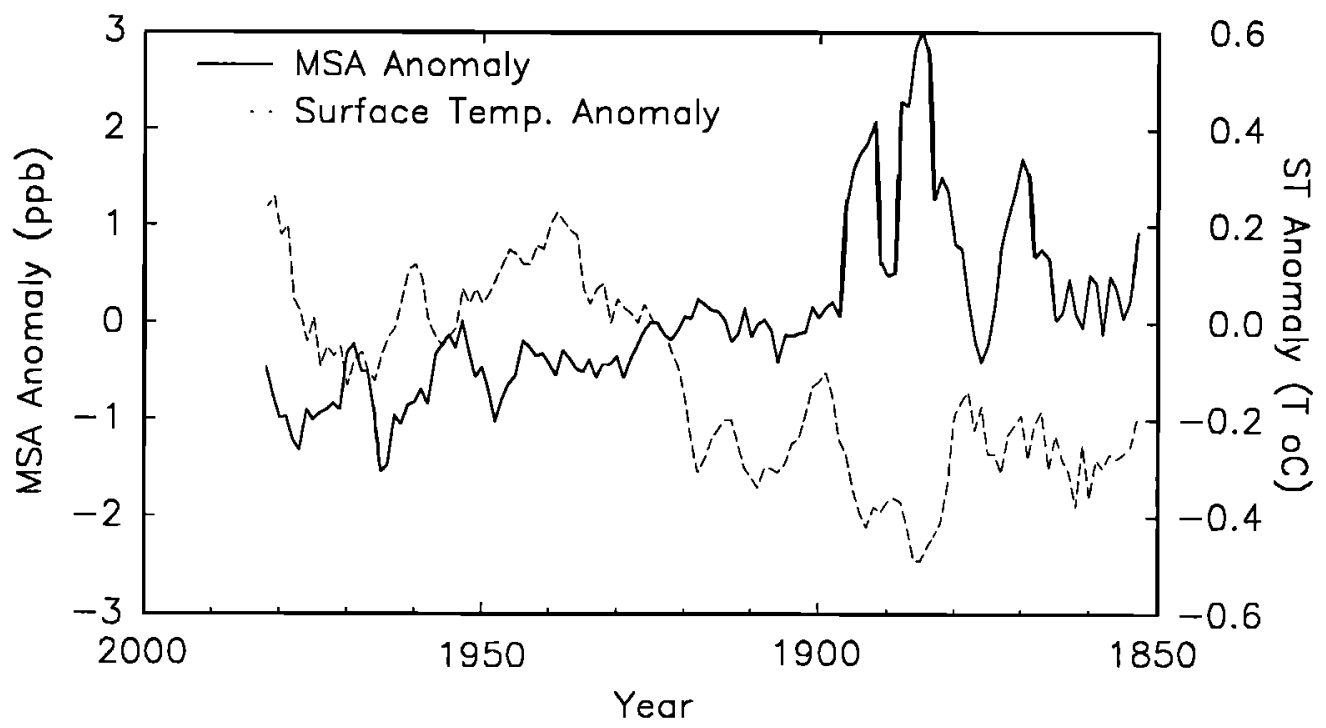

Fig. 6. Intercomparison of anomalies of surface air temperature and MSA (20D ice core record) between 1850 and 1984. The MSA and surface air temperature anomalies are calculated from the differences of the raw data and the mean. Plotted temperature and MSA data were a 5-year running average of the raw data. 
nitrate radical may be significant at lower latitudes during both the summer and the winter under polluted conditions [Atkinson et al., 1984; Winer et al., 1984; Andreae et al., 1985].

In the 20D ice core we can compare the MSA and nitrate ion records for evidence of the influence of $\mathrm{NO}_{\mathrm{x}}$ on the atmospheric sulfur cycle. Nitrate ion is the principle sink for atmospheric $\mathrm{NO}_{\mathrm{x}}$ and the ice core nitrate record at $20 \mathrm{D}$ closely reflects the historical inventory of $\mathrm{NO}_{\mathrm{x}}$ emissions for the North Atlantic [Dignon and Hameed, 1988; Mayewski et al., 1990]. As shown in Figure 5, nitrate concentrations increased slowly over preindustrial levels between 1900 and 1960 , then rapidly after 1960 . The mean nitrate concentration increased from $87.1 \pm 41.7$ ppb $(1 \sigma, n=34,1960-1965)$ to $128.6 \pm 71.8 \mathrm{ppb}(1 \sigma, \mathrm{n}=32$, 1980-1984). However, the MSA record shows no corresponding change after 1960 , suggesting that $\mathrm{NO}_{\mathrm{x}}$ levels are not a major factor determining the MSA yield from DMS oxidation.

\section{IMPLICATIONS FOR THE ORIGIN OF SULFUR IN THE GREENLAND ICE SHEET}

The depth profiles of MSA and non-sea-salt sulfate in the 20D ice core have several implications for the origin of sulfur in the Greenland ice sheet. The MSA fraction prior to 1900 in 20D is lower than the expected mean value of $30 \%$ in high-latitude marine boundary aerosols and exhibits larger variation than anticipated if a uniform biogenic source predominated over other sources. We suggest that both of these observations may be related to the latitudinal distribution of the DMS source. In modern marine boundary layer aerosols the MSA fraction is a strong function of latitude, with higher fractions at higher latitudes (Figure 7). This effect has been attributed to the temperature dependence of the reaction pathways of DMS oxidation [Hynes et al., 1986; Berresheim, 1987]. Because the mean MSA fraction in low-latitude and highlatitude regions is $5 \%$ and $30 \%$, respectively, the mean preindustrial MSA fraction of $15.8 \pm 11.1 \%(1 \sigma, n=628)$ observed in 20D ice suggests that low- and high-latitude sources contribute in roughly equal proportions to the precipitation chemistry of this region. It is interesting to note that Johnsen et al. [1989] reached similar conclusions regarding the importance of the low-latitude oceans as water vapor source regions for the Greenland ice sheet. The variability of the preindustrial MSA fraction in the ice core could reflect temporal variations in: (1) the sea-to-air flux of DMS from high- and lowlatitude source regions or (2) the efficiency of atmospheric transport from these regions to the site.

This interpretation of the MSA fraction inherently assumes that preindustrial non-sea-salt sulfate is predominantly of marine origin. Other potential sources include terrestrial biogenic sulfur gas emissions (other than DMS), terrestrial dust, and volcanic sulfate. Bates et al. [1992] estimate that the biogenic sulfur gas emissions from the continents totals less than $5 \%$ of the oceanic source, even in the northern hemisphere, so this source is insignificant. The contribution of aeolian dust to the atmospheric sulfate burden is also thought to be small. Much of the sulfate associated with dust transport events over tropical North Atlantic appears to be of pollutant origin [Savoie et al., 1989]. The volcanic source is potentially more important. Bates et al. [1992] estimated that volcanic sulfur emissions are roughly equal to oceanic

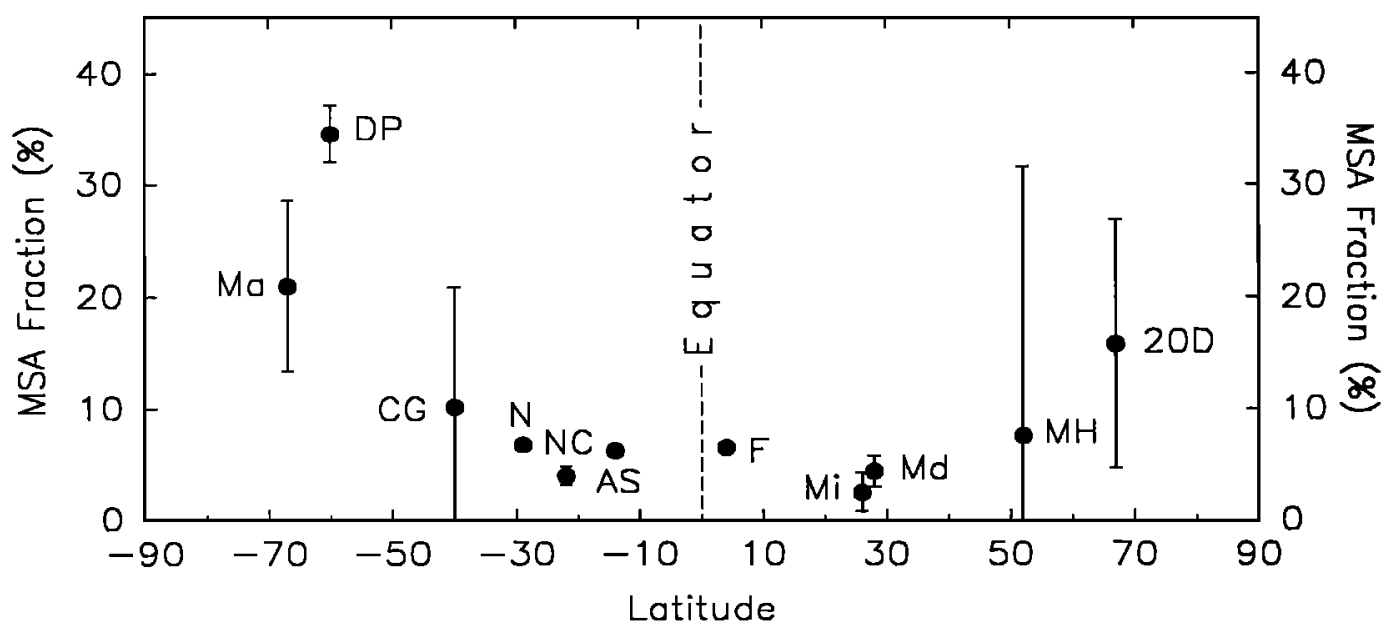

Fig. 7. Latitudinal variations in the mean MSA fraction in marine aerosols. The vertical bars at all sites are the standard deviations for the means. Miami, Midway, and Mace Head stations may include some influence of anthropogenic sulfate. The data from these sites represent the lower limit of the MSA fraction of the biogenic sulfur component. The locations are American Samoa (AS), Cape Grim (CG), Drake Passage (DP), Fanning (F), Mawson (Ma), Mace Head (MH), Miami (Mi), Midway (Md), New Caledonia (NC), and Norfolk (N). The mean MSA fraction and the standard deviations for the mean in the 20D ice core is also shown in this figure [Saltzman et al., 1983, 1986; Pszenny et al., 1989; Ayers et al., 1991; Saltzman and Whung. 1991; Whung, 1991; Savoie et al., 1992; Prospero et al., unpublished data, 1992]. 
emissions in the northern hemisphere, although there is considerable uncertainty in the estimates. Mayewski et al. [1986] estimated that erupting volcanic sulfate contained in the preindustrial 20D record comprises less than $10 \%$ of the total sulfate. We have used the MSA data to refine this calculation, as follows. A $t$ test was used to identify years which were significantly different from the mean nss $\mathrm{SO}_{4}^{2-}$ concentrations and MSA fractions at the $99 \%$ confidence interval. The years identified were 1783, $1800,1815,1835,1845$, and 1875 , corresponding to known eruptions of Laki (1783), Mount St. Helens (1800), Tambora (1815), Coseguina (1835), Hekla (1845), and Askja (1875). Removing these years from the data set gives a preindustrial MSA fraction of $16.1 \pm 11.4 \%(1 \sigma$, $n=587$ ), suggesting that eruptive volcanism has had a minor effect on non-sea-salt sulfate concentrations in the ice core. Berresheim and Jaeschke [1983] estimated that averaged noneruptive emissions may contribute approximately 10 times as much $\mathrm{SO}_{2}$ to the atmosphere than eruptive emissions over the period of 1961 and 1979. They suggested that on a global basis the volcanic sulfur emission could make up to $7 \%$ of the total sulfur flux. In contrast, Stoiber et al. [1987] estimated that noneruptive volcanic emissions are roughly $61 \%$ of eruptive sulfate emissions. If we remove years with known volcanic eruptions and estimated noneruptive volcanic $\mathrm{SO}_{2}$ from the total sulfate and, calculate the preindustrial MSA fraction in the 20D ice core, we obtain a mean value of $16.7 \pm 11.8 \%(1 \sigma, \mathrm{n}=587$, based on Berresheim and Jaeschke [1983]) and $16.1 \pm 11.4 \%(1 \sigma, \mathrm{n}=587$, based on Stoiber et al. [1987]). Thus including the noneruptive volcanic emissions has only a minor effect on the preindustrial MSA fraction. However, there is a lot of uncertainty in the estimation of noneruptive volcanism and currently there is no way to independently estimate the input of noneruptive volcanism from the ice core.

If we assume that the preindustrial MSA fraction represents the natural sulfur source to the Greenland ice sheet and that this value remained constant during the industrial period, we can estimate the impact of anthropogenic sulfate inputs on the region during the last century. Using the MSA fraction of $16 \%$ to characterize the natural sulfur input to the ice core, we calculate that anthropogenic sulfur contributed $50 \%$ of the total sulfur around 1890 and increased to $80 \%$ of the total sulfur at present. Taking into account the full range of variability in preindustrial MSA fractions ( $10 \%$ to $25 \%$ ), we estimate that approximately $60 \%$ to $85 \%$ of the total sulfur deposited at $20 \mathrm{D}$ over the last 20 years was derived from anthropogenic sources.

Different strategies for evaluating the importance of various sulfur sources give similar results. Langner and Rodhe [1991] used a three-dimensional transport model to calculate latitudinal variations of total sulfur (DMS, $\mathrm{SO}_{2}$, and $\mathrm{SO}_{4}{ }^{2-}$ ) and natural sulfur (DMS). Their results suggested that anthropogenic sulfate concentration is approximately $81 \%$ of the total sulfate in the northern hemisphere. Charlson et al. [1991] calculated the global distribution of the sulfate aerosol column burden and estimated that at least $66 \%$ of the total sulfate over the North Atlantic originated from anthropogenic emissions. At the present time the anthropogenic sulfate input dominates the sulfur budget in the Arctic.

Acknowledgments. This research was supported by National Science Foundation grants DPP-8700360 and DPP-8822600. Financial support was also received from grants EPA/NCSUAPP-03306 and EPRIRP23333-3.

\section{REFERENCES}

Andreae, M. O., Ocean-atmosphere interactions in the global biogeochemical sulfur cycle, Mar. Chent., 30, 1-29, 1990.

Andreae, M. O., R. J. Ferek, F. Bermond, K. P. Byrd, R. T. Engstrom, S. Hardin, P. D. Houmere, F. LeMarrec, H. Raemdonck, and R. B. Chatfield, Dimethyl sulfide in the marine atmosphere, J. Geophys. Res., 90, 12,891-12,900, 1985.

Atkinson, R., J. N. Pitts, Jr., and S. M. Aschmann, Tropospheric reactions of dimethyl sulfide with $\mathrm{NO}_{3}$ and $\mathrm{OH}$ radicals, $J$. Phys. Chem., 88, 1584-1587, 1984.

Ayers, G. P., J. P. Ivey, and H. S. Goodman, Sulfate and methanesulfonate in the maritime aerosol at Cape Grim, Tasmania, J. Atmos. Chem., 4, 173-185, 1986.

Ayers, G. P., J. P. Ivey, and R. W. Gillett, Coherence between seasonal cycles of dimethyl sulphide, methanesulphonate in marine air, Nature, 349, 404-406, 1991.

Barnes, I., V. Bastian, and K. H. Becker, Kinetics and mechanisms of the reaction of $\mathrm{OH}$ radicals with dimethyl sulfide, Int. J. Chem. Kinet., 20, 415-431, 1988.

Bates, T. S., B. K. Lamb, A. Guenther, J. Dignon, and R. E. Stoiber, Sulfur emissions to the atmosphere from natural sources, J. Atmos. Chem., 14, 315-337, 1992.

Berresheim, H., Biogenic sulfur emissions from the subantarctic and Antarctic oceans, J. Geopliys. Res., 92, 13,245-13,262, 1987.

Berresheim, H., and W. Jaeschke, The contribution of volcanoes to the global atmospheric sulfur budget, J. Geophys. Res., 88 . 3732-3740, 1983.

Berresheim, H., M. O. Andreae, G. P. Ayers, R. W. Gillett, J. T. Merrill, V. J. Davis, and W. L. Chameides, Airbome measurements of dimethylsulfide, sulfur dioxide, and aerosol ions over the Southern Ocean south of Australia, J. Atmos. Chem., 10, 341-370, 1990.

Burgermeister, S., and H. -W. Georgii, Distribution of methanesulfonate, nss-sulfate and dimethylsulfide over the Atlantic and the North Sea, J. Atmos. Environ., 10, 341-370, 1989.

Charlson, R. J., J. E. Lovelock, M. O. Andreae, and S. G. Warren, Oceanic phytoplankton, atmospheric sulphur, cloud albedo and climate, Nature, 326, 655-661, 1987.

Charlson, R. J., J. Langner, H. Rodhe, C. B. Levy, and S. G. Warren, Perturbation of the northern hemisphere radiative balance by backscattering from anthropogenic sulfate aerosols, Tellus, 43(AB), 152-163, 1991. 
Charlson, R. J., S. E. Schwartz, J. M. Hales, R. D. Cess, J. A Coakley, Jr., J. E. Hansen, and D. J. Hofmann, Climate forcing by anthropogenic aerosols, Science, 255, 423-430, 1992.

Davidson, C. I., S. Santhanam, R. C. Fortmann, and M. P. Olson, Almospheric transport and deposition of trace elements onto the Greenland ice sheet, Amos. Environ., 19. 2065-2081, 1985.

Daykin, E. P., and P. H. Wine, A study of the reactions of $\mathrm{NO}_{3}$ radicals with organic sulfides: Reactivity trend at $298 \mathrm{~K}$, Int. J. Chem. Kinet., 22, 1083-1094, 1990.

Dignon, J., and S. Hameed, Global emissions of nitrogen and sulfur oxides from 1960 to 1980, Air Pollut. Control Assoc. J., 39, 153, 1988.

Grosjean, D., Photooxidation of methyl sulfide, ethyl sulfide, and methanethiol, Environ. Sci. Technol., 18, 460-468, 1984.

Hatakeyama, S., and H. Akimoto, Reactions of $\mathrm{OH}$ radicals with methanethiol, dimethyl sulfide and dimethyl disulfide in air, J. Phys. Chem., 87, 2387-2395, 1983.

Herron, M. M., and C. C. Langway, Jr., Chloride, nitrate, and sulfate in the Dye 3 and Camp Century, Greenland ice cores, in Greenland Ice Core: Geophysics, Geochemistry, and the Environment, edited by C. C. Langway, Jr., H. Oeschger, and W. Dansgaard, AGU, Washington, DC, 1985.

Hynes, A. J., P. H. Wine, and D. H. Semmes, Kinetics and mechanism of $\mathrm{OH}$ reactions with organic sulfides, $J$. Phys. Chem., 90, 4148-4156, 1986.

Jensen, N. R., J. Hjorth, C. Lohse, H. Skov, and G. Restelli, Products and mechanism of the reaction between $\mathrm{NO}_{3}$ and dimethylsulphide in air, Atmos. Environ., 25, 1897-1904, 1991.

Johnsen, S. J., W. Dansgaard, and J. W. C. White, The origin of Arctic precipitation under present and glacial conditions, Tellus, 41(B), 452-468, 1989.

Jones, P. D., T. M. L., Wigley, and P. B. Wright, Global temperature variations between 1861 and 1984, Nature, 322, 430-434, 1986.

Langner, J., and H. Rodhe, A global three-dimensional model of the tropospheric sulfur cycle, J. Atmos. Chem., 13, 225-263, 1991.

Leck, C., Do marine phytoplankton contribute to the atmospheric sulfur balance of northern Europe?, thesis, Univ. of Stockholm, Sweden, 1989.

Legrand, M., C. Feniet-Saigne, E. S. Saltzınan, C. Germain, N. I. Barkov, and V. N. Petrov, Ice-core record of oceanic emissions of dimethylsulphide during the last climate cycle, Nature, 350, 144-146, 1991.

Mayewski, P. A., W. B. Lyons, M. J. Spencer, M. Twickler, W. Dansgaard, B. Koci, C. I. Davidson, and R. E. Honrath, Sulfate and nitrate concentrations from a South Greenland ice core, Science, 232, 975-977, 1986.

Mayewski, P. A., W. B. Lyons, M. J. Spencer, M. S. Twickler, C. F. Buck, and S. Whitlow, An ice-core record of atmospheric response to anthropogenic sulphate and nitrate, Nature, 346, 554-556, 1990.

Mysak, L. A., and D. K. Manak, Arctic sca-ice extent and anomalies, 1953-1984, Atmos. Ocean, 27, 376-405, 1989.
Neftel, A., J. Beer, H. Oeschger, F. Zurcher, and R. C. Finkel, Sulphate and nitrate concentration in snow from South Greenland 1895-1978, Nature, 314, 61 1-613, 1985.

Niki, H., P. D. Maker, C. M. Savage, and L. P. Breitenback, Spectroscopic and photochemical properties of $\mathrm{CH}_{3} \mathrm{SNO}, J$. Phys. Chem., 87, 7-9, 1983.

Pszenny, A. A. P., A. J. Castelle, R. A. Duce, and J. N. Galloway, A study of the sulfur cycle in the Antarctic marine boundary layer, J. Geophys. Res., 94, 9818-9830, 1989.

Rogers, J. C., The association between the North Atlantic Oscillation and the Southern Oscillation in the Northern Hemisphere, Mon. Weather Rev., 112, 1999-2015, 1984.

Saigne, C., and M. Legrand, Measurements of methanesulphonic acid in Antarctic ice, Nature, 330, 240-242, 1987.

Saltzman, E. S., D. L. Savoie, R. G. Zika, and J. M. Prospero, Methanesulfonic acid in the marine atmosphere, J. Geophys. Res., 88, 10,897-10,902, 1983.

Saltzman, E. S., D. L. Savoie, J. M. Prospero, and R. G. Zika, Methanesulfonic acid and non-sea-salt sulfate in Pacific air: Regional and seasonal variations, J. Atmos. Chem., 4, $227-$ $240,1986$.

Saltzman, E. S., and P. -Y. Whung, Methanesulfonate in the GISP2 ice core (Summit, Greenland): 700 A.D. to present, Eos, 72, 65, 1991.

Savoie, D. L., J. M. Prospero, and E. S. Saltzman, Non-sea-salt sulfate and nitrate in trade wind aerosols at Barbados: Evidence for long-range transport, J. Geophys. Res., 94, 50695080, 1989.

Savoie, D. L., J. M. Prospero, R. J. Larsen, and E. S. Saltzman, Nitrogen and sulfur species in aerosols at Mawson, Antarctica, and their relationship to natural radionuclides, $J$. Atmos. Chem., 14, 181-204, 1992.

Shaw, G. E., Bio-controlled thermostasis involving the sulfur cycle, Clim. Change, 5, 297-303, 1983.

Stoiber, R. E., S. N. Williams, and B. Hueber, Annual contribution of sulfur dioxide to the atmosphere by volcanoes, J. Volcanol. Geotherm. Res., 33, 1-8, 1987.

Tumer, S. M., G. Malin, and P. S. Liss, Dimethyl sulfide and (dimethylsulfonio)propionate in European coastal and shelf waters, in Biogenic Sulfur in the Environment, edited by E. S. Saltzman, and W. J. Cooper, ACS Symip. Ser. 393, chap. 12, ACS, Washington, DC, 450-458, 1989.

Tyndall, G. S., and A. R. Ravishankara, Atmospheric reactions of $\mathrm{CH}_{3} \mathrm{~S}$ radical, in Biogenic Sulfur in the Environment. edited by E. S. Saltzman, and W. J. Cooper, ACS Symp. Ser. 393, chapter 27, ACS, Washington, DC, 450-458, 1989.

Wallington, T. J., R. Atkinson, A. M. Winer, and J. N. Pitts, Jr., Absolute rate constants for the gas phase reactions of the $\mathrm{NO}_{3}$ radical with $\mathrm{CH}_{3} \mathrm{SH}, \mathrm{CH}_{3} \mathrm{SCH}_{3}, \mathrm{CH}_{3} \mathrm{SSCH}_{3}, \mathrm{H}_{2} \mathrm{~S}, \mathrm{SO}_{2}$ and $\mathrm{CH}_{3} \mathrm{OCH}_{3}$ over the temperature range $280-350 \mathrm{~K}$, J. Phys. Chem., 90, 5393-5396, 1986.

Walsh, J. E., and C. M. Johnson, An analysis of Arctic sea ice fluctuations, J. Phys. Oceanogr., 9, 580-591, 1979.

Whung, P. -Y., A study of methanesulfonic acid in ice cores, thesis, Univ. of Miami, Fla., 1991.

Winer, A. M., R. Atkinson, and J. N. Pitts, Jr., Gaseous nitrate 
radical: Possible nighttime atmospheric sink for biogenic organic coinpounds, Science, 224. 156-159, 1984.

Wu, Z., R. E. Newell, and J. Hsiung, Possible factors controlling global marine temperature variations over the past century, $J$. Geophys. Kes., 95, 11,799-11,810, 1990.

N. Gundestrup, Department of Geophysics, The Niels Bohr Institute, University of Copenhagen, Denmark.

P. A. Mayewski and M. J. Spencer, Institute for the Study of
Earth, Oceans, and Space, University of New Hampshire, Durham, NH 03824.

E. S. Saltzman and P. -Y. Whung, Rosenstiel School of Marine and Atmospheric Science, University of Miami, Miami, FL 33149-1098.

(Received Marcl 9, 1993; revised August 10, 1993; accepted August 10, 1993.) 